\title{
The Tax protein and the minichromosome maintenance protein complex MCM2-7 affect cell replication and viral transcription
}

\author{
Pierre-Yves Barez ${ }^{1,2^{*}}$, Alexandre Carpentier ${ }^{1,2}$, Mathieu Boxus ${ }^{1,2}$, Luc Willems ${ }^{1,2}$ \\ From 16th International Conference on Human Retroviruses: HTLV and Related Viruses \\ Montreal, Canada. 26-30 June 2013
}

The Tax oncoprotein plays a key role in the mechanisms of transformation, viral persistence and pathogenicity. Recently, we showed that Tax interacts with the minichromosome maintenance MCM2-7 helicase and binds to origins of DNA replication (Boxus et al, 2012 Blood 119:151). In fact, Tax modulates the spatiotemporal program of origin activation during the $\mathrm{S}$ phase of cell cycle. By this mechanism, Tax accelerates $\mathrm{S}$ phase progression through early firing of late replication origins. By interacting with the 5' LTR, the MCM2-7 complex also modulates Tax transactivation. Together, our data thus demonstrates that interaction between Tax and MCM2-7 modulates reprogramming of replication origins as well as viral transcription.

\section{Authors' details}

${ }^{1}$ Molecular and cellular Epigenetics, Interdisciplinary Cluster for Applied Genoproteomics (GIGA), University of Liège (ULg), Liège, Belgium. ${ }^{2}$ Molecular Biology Lab, Gembloux Agro Bio-Tech (ULg), Gembloux, Belgium.

Published: 7 January 2014

doi:10.1186/1742-4690-11-S1-P96

Cite this article as: Barez et al:: The Tax protein and the

minichromosome maintenance protein complex MCM2-7 affect cell

replication and viral transcription. Retrovirology 2014 11(Suppl 1):P96.

\footnotetext{
* Correspondence: py.barez@doct.ulg.ac.be

${ }^{1}$ Molecular and cellular Epigenetics, Interdisciplinary Cluster for Applied

Genoproteomics (GIGA), University of Liège (ULg), Liège, Belgium
}

Full list of author information is available at the end of the article
Submit your next manuscript to BioMed Central and take full advantage of:

- Convenient online submission

- Thorough peer review

- No space constraints or color figure charges

- Immediate publication on acceptance

- Inclusion in PubMed, CAS, Scopus and Google Scholar

- Research which is freely available for redistribution

Submit your manuscript at www.biomedcentral.com/submit
( Biomed Central 